Annandale, of whose help and inspiration he always spoke with affection. In this service he spent the rest of his life, with the exception of 1942-47, when he was director of fisheries for Bengal, returning to the Survey as its director in 1947. He was awarded the D.Sc. of the University of Punjab in 1922 and of Edinburgh in 1928.

Dr. Hora was an indefatigable and careful worker and his many publications cover various fields. He was primarily a systematic ichthyologist and the admitted authority on the freshwater fishes of India and adjacent lands. This statement without qualification could convey a false impression of his breadth of outlook. A number of his systematic papers contain bionomic and ecological observations. The latter aspect induced him to consider the adaptation and the evolution of the adaptive mechanisms of animals to the severe conditions in torrential streams, and his best-known publication in this field (Trans. Roy. Soc., 1930) is mainly devoted to insects.

In trying to comprehend the pattern of the dis. tribution of freshwater fishes in India and Malaya, Dr. Hora was led to consider the past geological history of these areas, and particularly that of the changing river systems brought about by Himalayan tectonic movements, and he put forward an ingenious explanation known as Hora's Satpura hypothesis. From an early stage he became interested in fisheries and means of increasing their efficiency with due regard to conservation. Later, he tackled the pond culture of fish with the view of increasing the food supply. The work and enthusiasm he put into this led to his being invited to open a discussion on the subject at the United Nations Conference at I Lake Success in 194.9. As fisheries consultant to the Food and Agriculture Organization he recently completed a "Handbook on Tropical Fish Culture".

Dr. Hora's command of Sanskrit enabled him to assess the knowledge of fish and fisheries possessed by the ancient Hindus and so make a significant contribution to the history of Indian science.

Dr. Hora was very active outside his own post and held important positions in various scientific societios and organizations. In recognition of his work he received a number of awards and honours, both in his own country and abroad; but he remained a most approachable and companionable man who willingly placed his knowledge at the disposal of others and, in particular, younger workers, many of whom he encouraged at critical stages in their careers. With his death India has lost a distinguished zoologist and loyal son, and many zoologists in other parts of the world will mourn a friend.

\section{H. O'DoNOGHUE}

SUNDER LAL HorA's research career was dominated by the materials and concepts he had inherited from Nelson Annandale, and he succeeded in creating new vistas of biological discovery in India. $\mathrm{He}$ took Indian ichthyology back to ancient history, prehistory and palæontology, and forwards to a systematized historical understanding continuously related to the material and cultural welfare of the Indian people. His emphasis throughout has been on relationships : from the immediate relationships he described to the larger relations between science, the humanities and politics.

$\mathrm{He}$ believed in generalizations based on the growth of intensive specialization into a many-branched unity.
At home he was a kindly patriarch, sometimes looking askance, but tolerantly, at the departures from Punjabi custom of his children; for him the day started with the prayers he had learned in childhood. He was humble, affectionate, considerate, addicted to tabulating routines which never reached the level of work-disciplines, eager for now experiences (he had travelled extensively in most countries), quick to laugh, and quite unable to control his passion for shop talk. On one occasion in London in the autumn of 1953, when he had talked zoology before, through and after dinner, Mrs. Hora whispered to a friend, with a wealth of loving understanding in her voice, "It is always so-nothing but fish !"

He lived a full life, with many sorrows and satisfactions, but remained astonishingly unsophisticated. After his first heart attack, he compromised with decadence by rising at 5.30 a.m. instead of earlier. $\mathrm{He}$ could not adjust himself to slowing down, and when I stayed with him in Calcutta a year ago, he made it clear that he would rather die at work than live as a semi-invalid. $\mathrm{He}$ died as he wished. $\mathrm{He}$ collapsed while presiding over a meeting of the Asiatic Society, but not before calling upon a member to take the chair. It was, characteristically, the last public gesture of a man whose life was distinguished by service and integrity. Cendic Dover

\section{Mr. Frank C. Willcocks}

IN a few years time Frank Willcocks may become one of those "that have no remembrance", because of his own modesty, and because of his isolation for thirty years in Egypt, yet those of us who had been his colleagues recognized his possession of "the Darwin touch'.

The influence of Theobald at Wye diverted his intention from farming to entomology, and so to an appointment with the Khedivial Agricultural Society when its eight-room laboratory was founded in 1904, a chemist and a botanist being his colleagues. Within two years he was able to outline the three major pests of cotton in a hundred pages of the Society's Year-book, and this succinct account by a nongraduate student aged twenty-four is still $a_{0}$ standard reference.

He remained with the Society until 1930, designing and founding its Cotton Museum as a side-issue, then retired to Bournemouth, whence he moved after the death of his French wife to a bungalow in the woods near Battle. The toil of struggle with his orchard and garden, workshop and houselkeeping, lonely except for his friends the cats, led him at last to move to the home of a niece in Gloucester, where he died unexpectedly only a few weeks later on December 18 at the age of seventy-two.

The introduction to his last publication in 1937 (the third volume of "Insect and Related Pests of Egypt") gives a clear impression of his sincerity and quiet wit, his humility towards the specialization of his juniors, and his gratitude for help by lesser men. He was a scientist in grain, the infinite capacity for taking pains being combined with a wide view across the field of his oconomic problems; he was a pioneer. In that last volume he devotes particular attention to one of his favourite insects, treating the molecrickets almost affectionately, alternating between the ingenious additions to our knowledge of them which he made and his repeated emphasis on know. ledge about them still to be sought. His dealings 